\title{
ФАКТОРЫ РИСКА И ЗАБОЛЕВАЕМОСТЬ САХАРНЫМ ДИАБЕТОМ В РЕСПУБЛИКЕ МОРДОВИЯ ПО ДАННЫМ ДИСПАНСЕРИЗАЦИИ ВЗРОСЛОГО НАСЕЛЕНИЯ
}

\author{
'Ямашкина Е.И., ${ }^{2}$ Юдина Н.Д., 'Есина М.В., 'Ефремова О.Н. \\ 'ФГБОУ ВО «МГУ им. Н.П. Огарева», Саранск \\ гГБУз РМ «Республиканская клиническая больница №4», Саранск
}

ЦЕЛЬ: провести анализ факторов риска и заболеваемости сахарным диабетом (СД) в Республике Мордовия по данным диспансеризации взрослого населения.

МАТЕРИАЛЫ И МЕТОДЫ: объектом Исследования являются сведения о диспансеризации населения Республики Мордовия в 2019 г. Были оценены заболеваемость СД, факторы риска СД 2 типа.

PЕзультАТЫ: по данным Регистра больных сахарным диабетом в Республике Мордовия, количество больных в 2019 г. составило 3418,89 на 100 тыс. населения. В настоящее время СД в Республике Мордовия болеют 3,4\% населения.

В 2019 г. 1-й этап диспансеризации прошли 357471 человек, 2-й этап - 59 865. На первом этапе население было проанкетировано, проведена антропометрия, определялся уровень глюкозы экспресс-методом. Гипергликемия выявлена у 18250 человек. Избыточная масса тела и ожирение выявлены у 64810 обследованных, артериальная гипертензия - у 141164 человек, гиперхолестеринемия - у 77338. Нерациональное питание выявлено у 108142 обследованных, низкая физическая активность - у 63285. Учитывая, что оценка гликированного гемоглобина и тест толерантности к глюкозе в настоящее время вынесены за рамки диспансеризации, на 2-м этапе диспансеризации дообследование углеводного обмена проведено только у 557 человек, при этом у 440 человек выявлено заболевание. Оценка липидного спектра крови проводилась у 4502 человек, дислипидемия подтверждена у 3781 из них.

СД выявлен у 11260 человек (3149,9 на 100 тыс. обследованных). Из них у 763 диагноз СД установлен впервые в жизни, или у 213,4 на 100 тыс. обследованных (44\% мужчин, 56\% женщин). Ожирение выявлено у 7301 человека (2042,4 на 100 тыс. обследованных), у 3764 - впервые в жизни (1052,9 на 100 тыс.).

Выводы: цифры, полученные при диспансеризации населения, согласуются с данными диарегистра, однако требуется дообследование углеводного обмена в рамках диспансеризации. Кроме того, диспансеризация является действенным методом выявления факторов риска СД 2 типа с целью дальнейшего профилактического консультирования. 